\title{
Spontaneous regeneration of eucalypts from seed production areas
}

\author{
Lygia Gago Miolaro • Antonio Natal Gonçalves • João Carlos Teixeira Mendes • \\ Rildo Moreira e Moreira • Arno Brune · Paulo Henrique Müller da Silva
}

Received: 30 August 2016/Accepted: 21 February 2017/Published online: 24 February 2017

(C) Springer International Publishing Switzerland 2017

\begin{abstract}
Eucalypt species are widely used around the world due to their high productivity; however there are some concerns about the invasiveness capacity of eucalypts. We assessed old seed production areas of commercial eucalypt species thought of being at risk of invasion in two places in Southeastern Brazil (Anhembi: lat: $22^{\circ} 28^{\prime} \mathrm{S}$; long: $48^{\circ} 04^{\prime} \mathrm{W}$; and Itatinga lat: $23^{\circ} 02^{\prime} \mathrm{S}$; long: $\left.48^{\circ} 38^{\prime} \mathrm{W}\right)$. We observed differences between places and among species. The species with the higher number of plantation stands and higher demand for seeds had more regeneration. Regeneration was recorded in only a few plots and trees and seedlings were found very close to the eucalypt stand, in sites where waste from seed
\end{abstract}

Electronic supplementary material The online version of this article (doi:10.1007/s10530-017-1397-1) contains supplementary material, which is available to authorized users.

L. G. Miolaro - A. N. Gonçalves · J. C. T. Mendes ·

R. Moreira e Moreira · P. H. M. da Silva ( $\square)$

Escola Superior de Agricultura "Luiz de Queiroz",

Universidade de São Paulo, Avenida Pádua Dias 11,

Caixa Postal 9, Piracicaba, SP CEP 13418-900, Brazil

e-mail: paulohenrique@ipef.br

L. G. Miolaro

e-mail: lygia.miolaro@gmail.com
A. N. Gonçalves
e-mail: natalgon@usp.br
J. C. T. Mendes
e-mail: jctmende@usp.br
R. Moreira e Moreira
e-mail: rmoreira@usp.br

harvesting is dumped. For spontaneous regeneration of eucalypts to occur there is a need for favorable environmental conditions. Such conditions may be created by human activities or natural events which suppress competition from vegetation.

Keywords Invasiveness - Invasibility · Anthropic action · Environmental conditions · Prediction · Competition

\section{Introduction}

Eucalypt species, considering Corymbia and Eucalyptus genus, are widely used around the world, due to

\author{
A. Brune \\ APSD- Ghana, Plot 27, Block 27, Nhyiaeso, Kumasi, \\ Ghana \\ P. H. M. da Silva \\ IPEF - Instituto de Pesquisas e Estudos Florestais, \\ Avenida Pádua Dias 11, Caixa Postal 530, Piracicaba, \\ SP CEP 13400-970, Brazil \\ P. H. M. da Silva \\ FCA - Faculdade de Ciências Agrárias, UNESP - \\ Universidade Estadual "Júlio de Mesquita Filho", \\ Botucatu, SP, Brazil
}


their good adaptability to environmental conditions enhanced by breeding programs and adequate management of stands (Gonçalves et al. 2013). Despite their high productivity, eucalypt plantations occasionally generate some concerns about possible environmental impacts (Silva et al. 2015); one of the concerns is capacity to become invasive. Eucalypt invasion is expected to occur less often than is the case with some other tree groups used in commercial forestry (Rejmanek and Richardson 2011, 2013), but few studies have sought reasons for the poor performance of eucalypts as invasive species. Invasiveness could be related to genetic characteristics of the species and to environmental conditions (Godfree et al. 2004; Tererai et al. 2013). Of the hundreds of eucalypt species only a few eucalypt species are planted in large numbers around the world (Harwood 2011) and problems due to invasiveness are very uncommon (Ruthrof 2004). However, eucalypt invasiveness is observed in some sites, such as E. globulus in some regions of California-United States (Ritter and Yost 2009), E. camaldulensis in a riparian vegetation in Western Cape and E. grandis in Mpumalanga-South Africa (Tererai et al. 2013; Forsyth et al. 2004). The spontaneous dispersion of eucalypt varies between regions and possibly increases with plantation age, in sites with exposed soil, disturbed by burning and without drought occurrence during germination time and establishment of seedlings (Lamcorbe et al. 2013; Silva et al. 2016). However there is a lack of information under field conditions where eucalypts have been established for a long time (Godfree et al. 2004; Flory et al. 2012). The aim of this study was to investigate spontaneous regeneration of old ( $>15$ years old) eucalypt seed production areas in two sites in southeastern Brazil.

\section{Materials and methods}

We selected important commercial eucalypt species from around the world Harwood (2011) which were mentioned to be of invasion risk (Gordon et al. 2012), in old stands ( $>15$ years) available in two Forest Experimental Stations of the University of São Paulo (Table 1).

We evaluated the four sides of each plantation using areas distanced $0-10,10-20$ and 20-30 $\mathrm{m}$ at the edge of each eucalypt stand (inside and outside of the plantation) and the road. There were seven plots per side (Supplementary material-Figure 1) of each evaluated plantation, totaling 28 per plantation stand.

The neighboring vegetation was (NV) classified as: commercial stand (mainly eucalypts plantation); natural vegetation ("Cerrado"-Brazilian savanna); and pasture.

Eucalypt (considering both Corymbia and Eucalyptus) regeneration was classified as: (i) small seedling $(<0.03 \mathrm{~m}$; few weeks); (ii) seedling $(0.03-1 \mathrm{~m}$; few months); and (iii) trees (higher than $1 \mathrm{~m}$; several months to years). Where there was regeneration, possible factors that could help the regeneration process were assessed, such as the occurrence of fire, gaps in the plantation, canopy remains and any other important considerations.

The regeneration data of seedlings and trees was analyzed for the variances $(p<0.05)$ using a fixed effect model in SAS (proc GLM). Regeneration data of small seedlings was not statistically analyzed because no small seedlings regeneration were found. Homogeneity of variances was tested and the normal distribution of residuals was obtained after data transformation $(\sqrt{0.5+x})$.

\section{Results}

There was a significant effect of species; experimental station and the interaction between species and experimental station on seedlings. For trees, there was a significant effect of species, plots, neighboring vegetation and the interaction between species $\mathrm{x}$ plots position $\mathrm{x}$ neighboring vegetation (Supplementary materialTable 2). In Itatinga Experimental Station there was a higher number of spontaneous regeneration in the eucalypt stand and in Anhembi Experimental Station it was higher in neighboring vegetation. However, in most plots evaluated no regeneration was observed; and where regeneration was observed, $97 \%$ of regenerating seedlings were found within $10 \mathrm{~m}$ of the eucalypt stand (Fig. 1), in both experimental stations.

In Anhembi Experimental Station, eight of the 57 plantations evaluated had some regeneration. The species that produced some regeneration were $C$. citriodora, E. grandis and E. urophylla. In Itatinga Experimental Station, five of the 11 plantations 
Table 1 Characterization of the eucalypt plantation in the two Forest Experimental Stations of the University of São Paulo

\begin{tabular}{|c|c|c|c|}
\hline Experimental station & Species & Plantations* & Age (years) \\
\hline Anhembi & Corymbia citriodora & 14 & $22-40$ \\
\hline lat: $22^{\circ} 28^{\prime} \mathrm{S}$ & C. torelliana & 3 & $27-36$ \\
\hline \multirow[t]{6}{*}{ long: $48^{\circ} 04^{\prime} \mathrm{W}$} & Eucalyptus camaldulensis & 1 & 35 \\
\hline & E. grandis & 7 & $25-39$ \\
\hline & E. pellita & 4 & $29-3$ \\
\hline & E. saligna & 2 & $17-39$ \\
\hline & E. tereticornis & 3 & $30-35$ \\
\hline & E. urophylla & 23 & $15-38$ \\
\hline Itatinga & C. citriodora & 1 & 18 \\
\hline lat: $23^{\circ} 02^{\prime} \mathrm{S}$ & C. torelliana & 1 & 18 \\
\hline \multirow[t]{7}{*}{ long: $48^{\circ} 38^{\prime} \mathrm{W}$} & E. camaldulensis & 1 & 18 \\
\hline & E. grandis & 1 & 18 \\
\hline & E. pellita & 1 & 18 \\
\hline & E. robusta & 2 & $18-20$ \\
\hline & E. saligna & 2 & $18-20$ \\
\hline & E. tereticornis & 1 & 18 \\
\hline & E. urophylla & 1 & 18 \\
\hline
\end{tabular}

* Most plantations are seed orchards or seed production areas. All plantations have been producing seeds for more than 12 years. The size of the plantations ranges from 0.25 to 4 ha and tree heights measure from 30 to $60 \mathrm{~m}$. In both experimental stations leaf-cutting ants are controlled annualy through the use of baits. The higher concentration of the species E. urophylla, C. citriodora and E. grandis in Anhembi is due to a larger demand for seeds of these species in Brazil

Itatinga Experimental Station

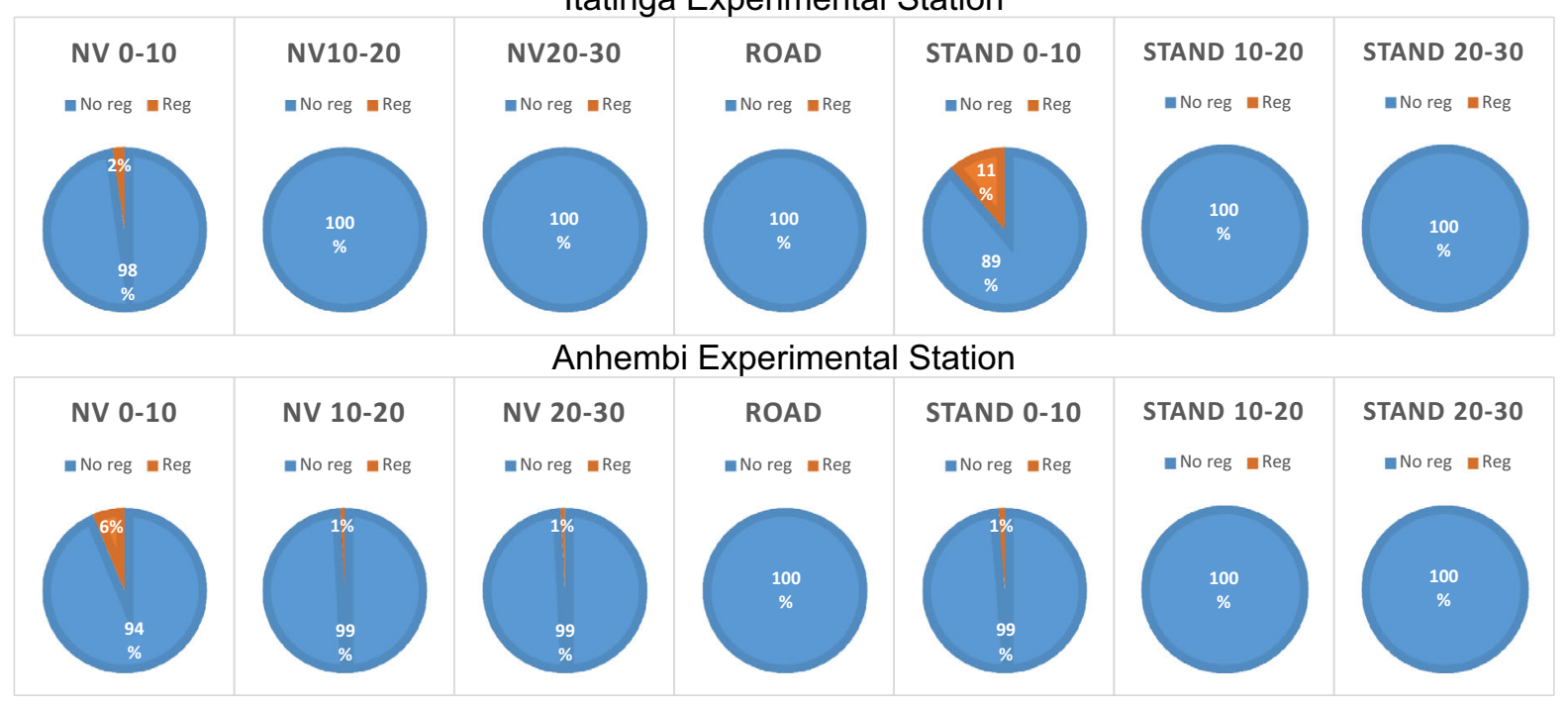

Fig. 1 Plots with eucalypt regeneration in two Experimental Stations. Legend: NV Neighboring Vegetation, Stand Commercial Eucalypt Stand

evaluated had some spontaneous regeneration. The species E. grandis, E. pellita, E. robusta, E. saligna and $E$. urophylla showed some regeneration and the species $C$. citriodora, C. torelliana, E. camaldulensis and E. tereticornis did not regenerate (Supplementary material_-Table 3). 
We observed some regeneration in gaps, where branches and other wastes of seed harvesting were commonly discarded and trees had fallen. In one $E$. grandis plantation, which had burned 2 years earlier, some regeneration of eucalypts was also found.

\section{Discussion}

The species with largest numbers of spontaneous regeneration belonged to the species Corymbia citriodora, Eucalyptus grandis and E. urophylla, which is consistent with the greater number of plantations and the high demand for seed (I. Vieira, IPEF Seeds Coordinator, personal communication). Still, the number of plots with regeneration was small and the highest number of trees and seedlings were found in a commercial stand and in neighboring vegetation very close to the stand, normally in gaps and places used to discard wastes of seed harvesting. The concentration of regeneration in the $0-10 \mathrm{~m}$ plots are due to the seed harvest waste discard and the poor dispersion capacity of eucalypt seeds as described by Callaham et al. (2013) and Calvino-Cancela and Rubido-Bara (2013). Typically, dispersal distances are similar to the height of the parent tree (Barber 1965).

Comparing both experimental stations, more regeneration of eucalypts was observed in Anhembi. This may have happened because this experimental station has a greater number and older plantations (more seed cycles) than Itatinga. In Anhembi Experimental Station, we observed the effects of fire and wastes of harvested seeds in gaps of the neighboring vegetation. Those are disturbances which leave the vegetation more susceptible to regeneration of eucalypts. Lorentz and Minogue (2015) argue that in an area with stable vegetation the chance of eucalypt regeneration is low; suggesting that a stable vegetation around the plantation acts as a buffer zone, as observed by Silva et al. (2017) in a genetically modified eucalypt plantation in Brazil surrounded by signal grass (Bracharia sp.).

The spontaneous establishment of seedlings increases with plantation age and may be enhanced in areas with regular rainfall and in disturbed areas (Larcombe et al. 2013). In older stands, which had a greater number of seed production cycles, the possibility of seed production under favourable environmental conditions increases; which in turn allows for some seed germination and seedling establishment. In an old area such as in this study, an important factor is the lack of intensive management such as weeding, which could favour seedling establishment (Silva et al. 2016). Additionally, leaf-cutting ant controls performed systematically in both experimental stations improve the possibility of eucalypt establishment. Predation by those ants may be one of the reasons for high mortality in the initial phase of seedling establishment (Silva et al. 2011). In Brazil, leaf-cutting by leaf ants are a cause of extensive damage to commercial eucalypt stands (Ferreira-Filho et al. 2015).

Even when some eucalypt seeds are able to germinate due to favorable environmental conditions, high mortality usually occurs during the initial phases of seedling development (Booth et al. 2015). In southeastern Brazil, where climatic conditions are slightly different from those of the origin of the eucalypts species (Silva et al. 2016), Brazilian native species have an advantage in adaptation and regenerate where eucalypt regeneration is not expected. In our study some specific conditions allowed for the establishment of some individuals. Therefore, spontaneous regeneration of eucalypt species is possible, typically close to eucalypt plantations and where some anthropic or natural actions, such as discarding wastes of harvested seed or burning had happened, which suppress natural vegetation.

In our study the spontaneous eucalypts regenerations is more related to invasibility of habitats than to the invasiveness capacity of eucalypts species due to the establishment that occurs in disturbed areas. Knowledge about environmental conditions that drives the establishment of eucalypts allows the development of models, which is important to help in the selection of the commercial areas and management to deal with invasive trees under different environmental conditions (Richardson et al. 2014; Richardson and Rejmanek 2011).

Acknowledgements We to thank the two anonymous reviewers and the associate editor Dr. Dave Richardson for their helpful and constructive suggestions and comments in our manuscript.

\section{References}

Barber HN (1965) Selection in natural plantations. Heredity 20:551-572 
Booth TH, Broadhurst LM, Pinkard E, Prober SM, Dillon SK, Bush D, Young AG (2015) Native forests and climate change: Lessons from eucalypts. For Ecol Manag 347:18-29. doi:10.1016/j.foreco.2015.03.002

Callaham MA, Stanturf JA, Hammond WJ, Rockwood DL, Wenk ES, O'Brien JJ (2013) Survey to evaluate escape of Eucalyptus spp. Seedlings from plantations in southeastern USA. Internat J For Res Article ID 946374, http://dx.doi. org/10.1155/2013/946374

Calvino-Cancela M, Rubido-Bara M (2013) Invasive potential of Eucalyptus globulus: seed dispersal, seedling recruitment and survival in habitats surrounding plantations. For Ecol Manag 305:129-137. doi:10.1016/j.foreco.2013.05. 037

Ferreira-Filho PJ, Wilcken CF, Neves DA, Pogetto MH, Carmo JB, Guerreiro JC, Zanuncio JC (2015) Does diatomaceous earth control leaf-cutter ants (Hymenoptera: Formicidae) in the eucalyptus plantations? J Econ Entomol. doi:10. 1093/jee/tov066

Flory SL, Lorentz KA, Gordon DR, Sollenberger LE (2012) Experimental approaches for evaluating the invasion risk of biofuel crops. Environ Res Lett 7:045904

Forsyth GG, Richardson DM, Brown PJ, van Wilgen BW (2004) A rapid assessment of the invasive status of Eucalyptus species in two South African provinces. S Afr J Sci 100:75-77

Godfree R, Lepschi B, Mallinson D (2004) Ecological filtering of exotic plants in an Australian sub-alpine environment. J Veg Sci 15:227-236

Gonçalves JLM, Alvares CA, Higa AR, Silva LD, Alfenas AC, Stahl J, Ferraz SFB, Lima WP, Brancalion PHS, Hubner A, Bouillet JPD, Laclau JP, Nouvellon Y, Epron D (2013) Integrating genetic and silvicultural strategies to minimize abiotic and biotic constraints in Brazilian eucalypt plantations. For Ecol Manag 301:6-21. doi:10.1016/j.foreco. 2012.12.030

Gordon DH, Flory LS, Cooper AL, Morris SK (2012) Assessing the invasion risk of eucalyptus in the United States using the Australian weed risk assessment. Int J For Res. Article ID 203768, p 7. http://dx.doi.org/10.1155/2012/203768

Harwood C (2011) New introductions - doing it right. In: Proceedings of the Conference "Developing a Eucalypt Resource for New Zealand”, 1(1993), p 10

Larcombe MJ, Silva JS, Vaillancourt RE, Potts BM (2013) Assessing the invasive potential of Eucalyptus globulus in Australia: quantification of wildling establishment from plantations. Biol Invasions 15:2763-2781. doi:10.1007/ s10530-013-0492-1
Lorentz KA, Minogue PJ (2015) Exotic Eucalyptus plantations in the southeastern US: risk assessment, management and policy approaches. Biol Invasions 17:1581-1593. doi:10. 1007/s10530-015-0844-0

Rejmánek M, Richardson DM (2011) Eucalypts. In: Simberloff D, Rejmánek M (eds) Encyclopedia of biological invasions. University of California Press, California, pp 203-209

Rejmánek M, Richardson DM (2013) Trees and shrubs as invasive alien species-2013 update of the global database. Divers Distrib 19:1093-1094

Richardson DM, Rejmánek M (2011) Trees and shrubs as invasive alien species-a global review. Div Distrib 17:788-809

Richardson DM, Hui C, Nunez M, Pauchard A (2014) Tree invasions: patterns, processes, challenges and opportunities. Biol Invasions 16:473-481

Ritter M, Yost J (2009) Diversity, reproduction, and potential for invasiveness of eucalyptus in California. Madroño 56:155-167. doi:10.3120/0024-9637-56.3.155

Ruthrof KX (2004) Invasion by Eucalyptus megacornuta of an urban Bushland in Southwestern Australia. Weed Technol 18:1376-1380

Silva PHM, Poggiani F, Sebbenn AM, Mori ES (2011) Can eucalyptus invade native forest fragments close to commercial stands? For Ecol Manag 261:2075-2080. doi:10. 1016/j.foreco.2011.03.001

Silva PHM, Sebbenn AM, Grattapaglia D (2015) Pollen-mediated gene flow across fragmented clonal stands of hybrid eucalypts in an exotic environment. For Ecol Manag 356:293-298. doi:10.1016/j.foreco.2014.12.005

Silva PHM, Bouillet J-P, de Paula RC (2016) Assessing the invasive potential of commercial Eucalyptus species in Brazil: germination and early establishment. For Ecol Manag 374:129-135. doi:10.1016/j.foreco.2016.05.007

Silva PHM, Sebbenn AM, Grattapaglia D, Conti JL Jr (2017) Realized pollen flow and wildling establishment from a genetically modified eucalypt field trial in Southeastern Brazil. For Ecol Manag 385:161-166. doi:10.1016/j. foreco.2016.11.043

Tererai F, Gaertner M, Jacobs SM, Richardson DM (2013) Eucalyptus invasions in riparian forests: effects on native vegetation community diversity, stand structure and composition. For Ecol Manag 297: 84-93. 10.1016/j.foreco. 2013.02.016 